\title{
THREE MONTHS IN POLAND. RESISTANCE PERFORMANCES ON WROCLAW'S STREETS
}

\author{
Joanna Panciuchin \\ University of Wroclaw, University of Lower Silesia, Poland \\ joanna.panciuchin@uwr.edu.pl
}

The article concerns resistance performances, which can be considered as one of the most important elements of modern democracies. Citizens are looking for new forms of influence on the representatives of the authorities and other decision-makers. Forms such as pickets, protests, demonstrations, and marches over the years have become the basic tools used by members of modern democratic societies. They reflect not only social problems and tensions resulting from systemic transformation (in terms of politics, law, and economics), but also strivings, aspirations, attitudes, cultural patterns of behavior and lifestyle changes. Of course, they take on various, often extensive forms, and their participants use a variety of performative strategies. In the colors used, in the materials used, in the sounds, shouts, slogans written on banners, in graphic signs, symbols the axiological order is present. After William J. T. Mitchell and Judith Butler, it can be stated that the very presence of a "physical" body of protesters in public space is a concrete form of resistance. The evoked performances, of course, are not limited only to being in a specific place and time. They have adopted and are still adopting very diverse forms, which in turn are closely related to the ideological layer. It is about the axiological order made present in the slogans, symbols, actions, street performances. In this article, the author attempts to conduct a cultural studies analysis of three events that took place in Wrocław between November 2018 and January 2019: a march on the occasion of the $100^{\text {th }}$ anniversary of regaining independence by Poland, a demonstration against the mass shooting of boars and the silent march after the assassination of the president of Gdańsk, Paweł Adamowicz. Each of these forms is characterized by different aesthetics, and also shows the diversity of ways of life, thinking of Polish citizens, and, consequently, the axes of disputes and conflicts dividing them.

Keywords: resistance, performance, manifestation, demonstration, march, Poland, city, public space, urban space, axiology.

DOI 10.23951/2312-7899-2019-1-57-68

\section{Introduction}

The political transformation of 1989 moved Poland to a parliamentary democracy, which is one the most popular form of indirect democracy 
today. As in most other democratic countries, with its advent, citizens began to look for alternative ways of exerting influence on the representatives of the authorities, and at the same time co-deciding on the fate of the state. Forms such as pickets, protests, demonstrations, and marches over the years have become the basic tools used by members of modern democratic societies. They reflect not only social problems and tensions resulting from systemic transformation (in terms of politics, law, and economics), but also strivings, aspirations, attitudes, cultural patterns of behavior and lifestyle changes. Attempts to influence the shape of the legislation in force and the related social order have become a permanent element of Poland's political landscape, regardless of the formations, groups, parties that have been or currently are in power. Of course, during three decades of democracy, various - sometimes unusually strong - divisions emerged (along the shared views, beliefs, values) and, accordingly, so did groups of interest seeking to realize their own benefits. The sudden disappearance of a "common enemy", in the Soviet period consolidating citizens and various opposition environments, brought to attention the formerly overlooked very different political agendas and entities, often with radically different ideological views. As a result of the transformation, competing visions of the country emerged, containing not only guidelines on aspirations and goals, sometimes quite utopian images of the future, but also differing narrations about forces or processes threatening the identity and sovereignty of the state.

In the above-mentioned forms of protest, taking the form of various resistance performances, the aspirations, expectations, conflicts and dreams of citizens are reflected, the citizens which can be placed in opposition to the functioning of indirect democracy and are better described as spokespersons "on behalf of themselves and others" rather than "instead of others". In this sense, resistance performances should be seen as elements of direct democracy ${ }^{1}$. Following William J. T. Mitchell and Judith Butler, it can be stated that the very presence of a "physical" body in public space (at a specific time and place) is a concrete form of resistance [Mitchell 2013; Butler 2016]. Protests, demonstrations, rallies etc. Of course, they take on various, often extensive forms, and their participants use a variety of performative strategies. By analyzing the activities discussed here, it is possible to show not only the diversity or significance of resistance performances but also by sketching

\footnotetext{
${ }^{1}$ The classic (described in the legislations) tools of direct democracy include referenda, plebiscites, veto, consultations, assemblies, people initiatives, and with the development of new technologies also Internet voting.
} 
different, intersecting (and converging) dispute axes - the values underlying them, which are the causative factors of human actions, can be pointed out [Pietraszko 2012]. In the colors used, in the materials used, in the sounds, shouts, slogans written on banners, in graphic signs, symbols (including gas masks, radioactivity signs, vehicle drawings, effigies of city presidents, black dress, umbrellas, booklet editions of the constitution in red cover, flags, drums, whistles, vuvuzelas) the axiological order is present. Aesthetic forms are to direct participants, witnesses, decision-makers and other actors of public life towards values that are the causative factor of these expressions. These values, in the light of Stanisław Pietraszko's (the founder of the first cultural studies in Poland) ideas, constitute the core of the most important, relatively autonomous component of the human universe. The causative factors mentioned here, constituting the most important determinant of the ways of people's lives, include biological, geographical, civilization, social factors, etc. When it comes to the dimension of culture, it is a space for the presence of practices undertaken for the sake of values. Thus, the culture - to which resistance performances certainly belong - is a special way of being a human.

Forms of protest take on a very diverse aesthetics, which in turn is closely related to the ideological layer (including ethical). Therefore, the visual aspect of performative situations becomes an extremely important component of the emerging new dimensions of democracy in this perspective. It should be assumed that this creativity and multitude of forms is governed by certain describable regularities. So, representatives of movements focused around a specific action usually create this visual layer collectively (negotiating its shape with each other). At the same time, they often use iconography that already exists globally or locally. In contrast to the sphere of art, it rarely happens that one author plays an absolutely decisive role in this process. Nevertheless, it is possible to indicate the flow of ideas, inspirations or even specific objects between the urban/public space of performances and the spaces of art (and vice versa). The aesthetics of these activities can hardly be considered as accidental. It is connected with strategies consciously developed by their initiators. Of course, visual elements are made not only as a reproduction of previously known emblems and images. They emerge primarily through the work of the imagination, seen here as crucial for the survival and further development of a democratic society. Utopia and creativity generate new senses and meanings. 
The perspective presented above will serve the author of this article to attempt a cultural study of three events that took place in Wrocław ${ }^{2}$ between November 2018 and January 2019: a march on the occasion of the 100th anniversary of regaining independence by Poland, a demonstration against the mass shooting of boars and the silent march after the assassination of the president of Gdańsk, Paweł Adamowicz. Each of these forms is characterized by different aesthetics, and also shows the diversity of ways of life, thinking of Polish citizens, and, consequently, the axes of disputes and conflicts dividing them.

\section{The 100th anniversary of regaining independence by Poland}

For several years, the National Independence Day falling on November 11 has been raising a lot of extreme emotions among public opinion, primarily due to the ever-stronger commitment to the organization of the celebrations by so-called national and extreme-right circles. In 2018, Poles celebrated the anniversary of regaining freedom - one hundred years of independence. Therefore, this anniversary included not only the crucial day of 11th November. Plans for the whole of 2018 have been filled with various cultural, social and educational initiatives aimed at, among others, stimulating the spirit of patriotism among citizens, promoting Polish scientific and artistic achievements abroad, as well as expanding the historical knowledge of Poles. At the climax of the celebration of the anniversary, that is, on the symbolic November the 11th, nationwide events, concerts, performances, meetings, but also organized grassroots-organized forms such as marches, demonstrations, and counter-demonstrations, took place.

In Wroclaw, we have also had two types of celebrations of the $\mathrm{Na}-$ tional Independence Day. The first activity was organized under the name "Joyful Parade of Independence" by the city hall and three selfgovernment institutions, i.e. the Wrocław Culture Zone, the Wrocław Social Development Center and the Depot History Centre managed by the Remembrance and Future Centre. In this case, we were dealing with a planned form having its scenario, produced by a team of specialists. Four white and red parades passed through the city, consisting mainly of students from Wroclaw schools that converged at Plac Wolności (Freedom Square). There, official ceremonies took place along with

\footnotetext{
${ }^{2}$ Only the events taking place in Wrocław will be discussed here, due to the place of residence of the author of the article. The aspect of participation and living observation of the performances is very important here.
} 
a military ceremony, a parade of uniformed formation, singing the national anthem and listening to speeches of the city president and other decision-makers. The participants of the celebrations brought with them flags, flowers, and umbrellas in national colors. Many of them also painted their faces in white and red. Interestingly, there have been many items present, which normally are used by fans during the Polish national team's matches, namely white and red wigs, scarves and "jesters' hats". We are dealing here with an example of the flow of symbolism between the sphere of sport and the celebration of the national holiday. The "Joyful Parade of Independence" took the form of a spectacle, the symbolism used by its participants was subordinated to the vision of the organizers. This event can not be considered as a bottom-up activity.

In turn, in the afternoon from the Main Railway Station the "March of the Independent Poland" set off, organized by "the milieu of Wroclaw patriots and nationalists, as well as fans of Śląsk Wrocław" football team [Międlar 2018]. It should be noted at the outset that this march took place under the officially registered slogan "Life and death for the Nation". The leaders of the manifestation, Jacek Międlar ${ }^{3}$ and Piotr Rybak $^{4}$, explained that this is a direct reference to the intellectual legacy of the pre-war National Radical Camp. Such justification was accepted not only by the Municipality of Wrocław - permission was issued for a public gathering - but also by journalists who distributed information about the event in numerous articles. In reality, however, the slogan "Life and Death for the Nation" was not attributed solely to pre-war national thinkers. It was also used by the NOB National Combat Organization, i.e. a national-radical, paramilitary unit of the illegal (often described as fascist or fascist) RNR "Falanga" ${ }^{5}$ organization operating in 1935-1939, that is in the period of the Second Polish Republic. The NOB "Life and Death for the Nation" was initially called the "Hand with Sword" Combat Unit. Its members took part in regular military activities - their role was to engage in active revolutionary struggle. The NOB was responsible for shots fired on the May Day parade (1937) organized by the Bund, that is, the "Universal Jewish Workers Union in Lithuania, Poland, and Russia", or bomb attacks on

\footnotetext{
${ }^{3}$ An ex-priest, currently an activist of national and extreme right circles, Międlar repeatedly caused scandals among Polish public opinion due to public statements of a racist, xenophobic and chauvinistic nature.

${ }^{4}$ An activist of national and extreme right groups. In 2018, he was convicted for burning a Jew's effigy at the Market Square in Wrocław during a manifestation on the occasion of Independence Day in 2016 (also co-organized it with Jacek Międlar).

${ }^{5}$ The Falanga ideology consisted not only of nationalism, anti-democraticism or anti-communism, but also anti-Semitism.
} 
the headquarters of the Polish Teachers' Union in Warsaw and Lodz What is important, RNR used the symbol of the phalanx, or geometrized representation of the hand holding the sword, which today is clearly identified not only with national but also with fascist and Nazi ideology. Due to many scandals related to the use of hate symbols during demonstrations organized by national and right-wing circles, as well as attempts to block the march planned for November 11, 2018, in Wrocław by the then city president Rafał Dutkiewicz, the organizers of the March of Independent Poland decided not to use phalanxes overtly. This symbol was hidden under the "Life and death for the Nation" slogan. In this way, the slogan does not refer only to patriotic values (understood in their extreme, as giving life for the homeland, not as everyday segregation of trash or participation in elections), but also to fascist and extreme national ideologies, which may not be decoded by people who do not know the history of national-radical camp.

In order to characterize the performative layer of the march, as well as try to answer the question, what were these events resisting, it is worth quoting from the preview of the demonstration. "We are convinced that our march will once again become the pride of Wroclaw, the gathering of Polish patriots above divisions, solemn celebration and strong opposition to anti-Polonism, which is gaining in size and has been plaguing the capital of Lower Silesia for years. We are aware that also this time hearing on the March of Independent Poland, leftist circles and Jewish settlers living in our homeland will get a white fever, and the anti-Polish adventurers will want to disturb our march and lead to a fuss. It will never happen!" wrote Jacek Międlar on the wprawo.pl website $^{7}$ [Międlar 2018]. The use of terms such as "anti-Polonism" or "anti-Polish adventurers" clearly indicates the fear of the globalization and cosmopolitization processes, and above all the reluctance towards political integration structures such as the European Union. In turn, the phrase "Jewish settlers living in our homeland" testifies to anti-Semitism and xenophobia. The fragment quoted here makes it possible to conclude that the Wrocław "March of Independent Poland" under the slogan "Life and death for the Nation" was to enable not only celebrating the day, manifesting patriotic attitude and attachment to tradition, but also to demonstrate the opposition to people and ways of thinking which proclaim openness, tolerance and weakening of borders between states and nations, thus threatening the very idea of a nation state.

\footnotetext{
${ }^{6}$ For providing information on the functioning of the slogan "Life and death for the Nation" in pre-war Poland, the author of this text would like to thank PhD Isolde Topp-Wójtowicz.

${ }^{7}$ It is worth noting that Mr. Międlar is the founder and editor-in-chief of this portal.
} 
The route of the march beginning at the Main Railway Station ${ }^{8}$ was about two kilometers long. It ran through some of the most important Wroclaw arteries: Kołłątaja Street, Dominikański Square (a junction of numerous tram and bus lines), Kazimierza Wielkiego Street up to Gołębi Square at the City Hall building. It is estimated that around nine thousand people participated in the parade. Its participants belonged to various age groups: youth, adults, families with children and the elderly marched. A large and extremely compact group, which in fact created the front of the march, were fans of the local football team Śląsk Wrocław. The march had a very extensive performative and visual layer. It was accompanied by speeches, cheers, banners, flags, music, songs, and pyrotechnics. The procession was led by a truck with a platform for the leaders of the event. It was a kind of a moving stage from which people were constantly speaking, chants and songs were initiated. The vehicle also had a professional sound system, making the event not only visible but also audible even from a distance. In the case of the "March of Independent Poland", it was extremely important to use a wide variety of extremely powerful visual and audio media. Such a strategy was to maximize the impact of the assembly - both "internally", strengthening the sense of agency and significance of the participants of the performance, as well as "externally", testifying to the strength of the marching. Participants of the assembly chanted slogans such as: "Poland, white and red", "honor and glory to the heroes", "hail to Great Poland", "pride, pride, national pride", "God, honor and fatherland", "national radicalism", "WKS"10, "anti-Bandera Poland", "from the cradle to the grave, Polish Vilnius, Polish Lviv", "away with the commune", "use a sickle, use a hammer, smash the red rabble", "away with the Brussels occupation", "here is Poland, not Polin"11. On the banners, one could read "Your tenements, our streets", "Life and death for the Nation"12, "Death to the enemies of the Fatherland", "Pole, Hungary, two nephews", "March of Patriots", "Better dead than red". The musical layer of the march was very rich, too. Apart from the chanting cited here, one could also hear Polish hip-hop songs, known from the

\footnotetext{
${ }^{8}$ Wrocław's national groupings often make the Main Station the starting point of their demonstrations.

${ }_{9}^{9}$ In case of this chant, we are dealing with the transition from the sphere of supporting national teams to the sphere of public space demonstrations.

${ }_{10}$ Abbreviation of the local football team - WKS Śląsk Wrocław.

${ }^{11}$ The slogan refers to the Polin Museum of Polish Jews in Warsaw, and at the same time refers to long tradition conspiracy theories of the Jews supposedly taking over the country's government (in this case, it is suggested that this is what is happening in nowadays Poland). This is a manifestation of anti-Semitism.

${ }^{12}$ Next to the slogan there was a symbol of a phalanx and a Celtic cross.
} 
football match tifo displays "Forward, Polish" performed by Marek Torzewski, patriotic song "Rota"13, Catholic religious song "God, save Poland"14 and "Poland Is Not Yet Lost" (Dabrowski's Mazurka, the national anthem).

All the examples of slogans, banners, and sounds quoted here refer us to the axiological sphere. Ways of life and being, existing and practiced individually on a daily basis, become "most visible" and "clearest" when many people will gather in a public space at the right place and time. However, the streets are governed not only by the bodies of the participants of the rally but above all by the ideas and values, constituting the causative factor of human actions (in the sphere of culture) mentioned at the beginning of this article.

\section{Mass boar culling}

In February 2014, the first Polish cases of ASF, the African swine fever virus, were detected in several feral pigs (probably originating from Belarus). The disease is characterized by high mortality, it is also easily transferred from wild animals to farm animals - in this case, domestic pigs. What is extremely important, especially if this topic is viewed from the perspective of posthuman reflection, the infection does not occur through direct contact between wild boar and pig (they have no contact with each other). Therefore, the "carrier" of germs is a human being without complying with the rules of safety and hygiene, he brings a virus to the pigsty on shoes, working clothes, litter or feed. In January 2018, the Supreme Audit Office published a report indicating that as many as 74 percents of the farms did not have the safeguards recommended in the context of ASF [Kalinowska 2019]. Although the disease has been occurring in Poland since 2014, so far the state authorities have not taken too much action to prevent the spread of the virus, although the occurrence of ASF can bring many negative consequences for the country's economy ${ }^{15}$. At the beginning of 2019, the Polish media published information of the mass shooting of wild boars planned by the Ministry of the Environment on three January weekends (12-13, 19-20 and 26-27 January). The action was justified by the need to fight

\footnotetext{
${ }^{13}$ The song's text is a poem by Maria Konopnicka. After Poland regained independence, it was one of the candidates for the national anthem. However, the choice ultimately fell on "Dąbrowski's Mazurka" with the lyrics by Józef Wybicki.

${ }^{14}$ This song also competed for the recognition as a national anthem.

${ }^{15}$ You cannot import pigs, fresh and frozen meat from the country where the disease has been reported to an ASF-free country. This has a large impact on meat export profits.
} 
African swine fever disease. The decision of the minister, Henryk Kowalczyk, aroused much controversy among scientists, ecologists, veterinarians and the hunters themselves. It was pointed out that the massive boar culling has been just a propaganda stunt, in fact not able to stop the ASF spread. On the contrary, it may contribute not only to the elimination of this species from Polish forests, but also to affect the number of other animals, such as wolves, and spread the disease further. Namely, it was argued that through such extensive hunting in a large area, wild boars would travel long distances, which would result in increased contacts between packets and at the same time increased risk of disease transmission to other animals [Łakomski 2019]. Due to many doubts as to the necessity of shooting and objections regarding the actual use by hunters of the adopted safety procedures (there were cases where hunters left dead boars in the forest, which in the context of the fight against ASF is unacceptable) - activists tried to block hunting or at least observed and recorded them. In turn, the citizens of several Polish cities organized pickets and demonstrations to express their opposition to the shooting of these animals.

On January 12, a demonstration under the slogan "Leave the boars in peace!" took place in the Wrocław Market Square, was organized on the initiative of Anna Witańska, a member of the Wrocław Anti-Hunting Movement. In the announcement of the event posted on the Facebook portal, one could read that the rally is meant as "peaceful protest against the slaughter of wild boars in Poland planned by the Ministry. Culling is not a solution". Around two hundred Wrocław residents gathered around the pillory, which very often plays the role of a rostrum for speakers during protests. The audience chanted: "the boar does not transmit the disease, let the minister apologize", "the boar is wild, not bad", "stop the slaughter of wild boars", "slaughter of wild boars will not bring results", "Boars, let them live! Deer, let them live! Wolves, let them live! Bison, let them live! Foxes, let them live!", "together for wild boars, together for forests!", "today it's boar, tomorrow it's...?", "wildlife, it's not politics", "politics away from wild boar!". The banners read: "The greatest plague is incompetence", "Stop the slaughter of wild boars! Ministers to resign!", "Boar - the engineer of the forest", "At what age did you grow out of compassion?", "ASF is spread by the people, not the boars", "Boars above the elites"16, "Do not kill", "Slaughter of the boar will not give results", "Pigs to doctor", "You will not wash this blood off your hands!". At the visual layer of the protest there were also

\footnotetext{
${ }^{16}$ This inscription was accompanied by the symbol used by the anarchists (the letter A inscribed in a circle).
} 
drawings depicting the boars, often made and held by children. Some of the participants of the manifestation wore masks referring to the heads of animals, in defense of which they came in January to the Wroclaw Market Square. The element that distinguishes this resistance performance from other protests was the use of many playful elements - from the above-mentioned drawings, through the slogans referring to the well-known poem by Jan Brzechwa entitled "Wild is the boar", to the common singing of the altered version of the popular birthday song instead of "100 years, 100 years, may they live" it was "100 years, 100 years, may they dig". It is also important that among all the emblems and performances there were no signs or symbols referring to parties or political groups. The assembly did not have its clear leaders either.

In this case, the "Leave boars in peace!" rally promotes resistance not only to the environmental policy in force in Poland but also to global processes.

\section{Murder of the President of Gdańsk}

On 13 January 2019, the 27th Finale of the Great Orchestra of Christmas Charity took place, the largest and most popular charity event in Poland. As part of the finale, concerts, performances, workshops, auctions, meetings were held in many cities, towns, and villages both in Poland and abroad - during which the volunteers of the Great Orchestra of Christmas Charity were collecting money for, among others, medical equipment. An obligatory element of each finale is the so-called "Light up to the sky", meaning a fireworks display at 20:00 or, in the "pro-animal" version, a laser show or cold fires. On January the $13^{\text {th }}$ a concert "Gdańsk for the Great Orchestra of Christmas Charity" was organized in Gdańsk at Targ Węglowy. Just before 20:00, Paweł Adamowicz, the city president, gave a short speech. During the traditional countdown to "The Light", Stefan W. rushed to the stage and stabbed the President three times with a knife. Due to the inadequate quick reaction of the security services, the attacker managed to walk over the stage and shout to the microphone: "Hello! Hello! My name is Stefan $\mathrm{W}<$...>. I sat innocently in prison. I sat innocently in prison. The Civic Platform ${ }^{17}$ tortured me. That's why Adamowicz died". After the assassin was overpowered, Adamowicz was transported to the hospital, where he died on the next day.

\footnotetext{
${ }_{17}$ Platforma Obywatelska is a formerly ruling political party, currently the second force in the Polish parliament.
} 
The tragic event dominated media coverage, as well as people's conversations in homes, workplaces, on the streets. The murder of the president of one of the largest Polish cities caused terror and confusion among citizens. Adamowicz was known for his policy of openness. It was extremely important for him to respect cultural and ethnic diversity (he cooperated with the Kashubian minority among others, he also actively contributed to Polish-German reconcilement). As one of the few city mayors, he was involved in the process of implementing the immigrant integration program. He also manifested his openness and tolerance with personal participation in the Gdańsk Equality March. He repeatedly expressed opposition and dissatisfaction with the policy of the ruling party, Law and Justice. He also struggled with insults, threats, and harassment by opponents of ideological views many times ${ }^{18}$. The death of President Adamowicz thus became a painful proof of the raging policy of hatred. The murder of a person who for many was a model not only of an ideal local government but also a wise, tolerant politician, meant the triumph of violence. The shock was compounded by the situation in which the attack was carried out, i.e. during the finale of a major charity event.

In response to the events of 13 and 14 January, memorial marches were organized in many Polish cities, which were intended not only to help the communal experience of mourning but also to express protest to hate speech and violence. In Wrocław, the parade was planned for 18.01 , that is a day before the funeral ceremony. The march took place in silence. Its visual layer consisted of a few white and red flags, candles and one small inscription "Stop violence, hatred, divisions". On Solny Square, where the congregation was completed, the Polish national anthem was sung, and the "Sound of silence" performed by the Disturbed band was playing. This song became a kind of symbol of mourning after Adamowicz's death. It was first played on January 14 in Gdansk. The title "Sound of silence" is supposed to express not only regret, silence and emptiness following loss but also fear and bitterness towards the staunchly opposed by Paweł Adamowicz - hate speech, constantly spreading not only on the Internet, but also entering the public debate.

The march of 18 January was an example of manifesting a protest by gathering human bodies in a specific place and time. Lack of chanted passwords or banners does not diminish the power of the demonstration. Energy of allied bodies, occupying public space, building a community of resistance to violence, intolerance and hate speech are the basic distinguishing traits of marches after Paweł Adamowicz's death.

\footnotetext{
${ }^{18}$ A national-radical group, the All-Polish Youth, issued a death certificate of Paweł Adamowicz.
} 
The three examples of resistance performances presented in this article took place only within three months - from November 2018 to January 2019. This seems to show the current concentration of conflicts at the intersections of axiotic axes.

\section{REFERENCES}

Butler 2016 - Butler J. Zapiski o performatywnej teorii zgromadzeń. Warszawa, 2016.

Kalinowska 2019 - Kalinowska D. Masowy odstrzał dzików. Naukowiec: Polowania mogą przyczynić się do rozprzestrzeniania się ASF. Dziennik.pl. 2019. January 11. URL: https://wiadomosci.dziennik.pl/ wydarzenia/artykuly/588911,o-chodzi-w-sporze-o-dziki-dzikodstrzal-polowanie-rzad-pis-polityka-mysliwy-asf.html.

Łakomski 2019 - Łakomski G. Szef związku łowieckiego podaje się do dymisji. „Minister potrzebował kozła ofiarnego”. TVN24.pl. 2019. January 17. URL: https://www.tvn24.pl/wiadomosci-z-kraju,3/odstrzaldzikow-szef-zwiazku-lowieckiego-odchodzi,901281.html.

Międlar 2018 - Międlar J. Marsz Polski Niepodległej we Wrocławiu 11.11.2018. Życie i śmierć dla narodu! Wprawo.pl. 2018. November. URL: https://wprawo.pl/2018/10/30/marsz-polski-niepodleglej-wewroclawiu-11-11-2018-zycie-i-smierc-dla-narodu-zapraszamy/.

Mitchell 2013 - Mitchell W. J. T. Obraz, przestrzeń, rewolucja. Wszystkie sztuki okupacji. Widok. Teorie i praktyki kultury wizualnej. 2013. 3. URL: http://pismowidok.org/index.php/one/article/view/102/164\#sd footnote1sym.

Pietraszko 2012 - Pietraszko S. Kultura. Studia teoretyczne i metodologiczne. Wrocław, 2012. 